\title{
Penguatan Sense of Community pada Remaja Rusunawa Rawa Bebek Jakarta
}

\author{
Strengthening the Sense of Community among Adolescents \\ of Rusunawa Rawa Bebek Jakarta
}

Johan Satria Putra ${ }^{1 凶}$, Sunu Bagaskara ${ }^{2}$, Octaviani I. Ranakusuma ${ }^{3}$, \& Entin Nurhayati ${ }^{4}$

${ }^{1234}$ Fakultas Psikologi, Universitas YARSI Jakarta, Indonesia

凶johansatriaputra@gmail.com
Article history:

Submitted: 3 May 2021

Accepted: 8 July 2021

Published: 17 July 2021

\begin{abstract}
In most cases, simple rented flats (Rusunawa) in Jabodetabek have residents with low economic levels and quality of life. One of the factors that may improve the quality of life is the social support among residents determined by the sense of community. In Rusunawa Rawa Bebek, for instance, the residents comes from various areas in Indonesia, so that the sense of community among them is weak. Therefore, the purpose of this social intervention program is to strengthen the sense of community among adolescents in Rusunawa Rawa Bebek. The program consist of assessment and training carried out for a full day, including presentations and games that lead to the character building of community members to have a good emotion and a sense of community. The training was conducted to 17 teenagers from Karang Taruna Rusunawa Rawa Bebek. The change of sense of community is measured by pre-test and post-test before and after training, using the BSCS (Brief Sense of Community Scale), by examining changes in the average score. The results of the statistical analysis showed an increase in the level of sense of community of the participants after training, though not quite significant.
\end{abstract}

Keywords: adolescent; Rusunawa Rawa Bebek; sense of community; simple rented flats.

Abstrak: Rusunawa di Jabodetabek umumnya dihuni oleh penduduk dengan tingkat ekonomi dan kualitas hidup yang rendah. Salah satu faktor yang dapat meningkatkan kualitas hidup adalah dukungan sosial antar warga yang ditentukan oleh rasa kebersamaan. Di Rusunawa Rawa Bebek, misalnya, penduduknya berasal dari berbagai daerah di Indonesia, sehingga rasa kebersamaan di antara mereka masih lemah. Oleh karena itu, tujuan dari program intervensi sosial ini adalah untuk memperkuat rasa kebersamaan di kalangan remaja di Rusunawa Rawa Bebek. Program terdiri dari penilaian dan pelatihan yang dilakukan selama satu hari penuh, termasuk presentasi dan permainan yang mengarah pada pembentukan karakter anggota komunitas untuk memiliki emosi dan rasa komunitas yang baik. Pelatihan dilakukan kepada 17 remaja dari Karang Taruna Rusunawa Rawa Bebek. Perubahan sense of community diukur dengan pre-test dan post-test sebelum dan sesudah pelatihan, menggunakan BSCS (Brief Sense of Community Scale), dengan memeriksa perubahan skor rata-rata. Hasil analisis statistik menunjukkan adanya peningkatan tingkat sense of community peserta setelah pelatihan, meskipun tidak cukup signifikan.

Kata kunci: rasa kebersamaan; remaja; rusunawa; Rusunawa Rawa Bebek; sense of community.

P-ISSN 2715-7997 E-ISSN 2716-0750 (C) 2021 The Author(s).

Published by LP2M INSURI Ponorogo. This is an open access article under the CC BY-SA 4.0 license.

doi: 10.37680/amalee.v2i2.800 


\section{Pendahuluan}

Berdasarkan data terkini dari Badan Pusat Statistik (BPS) Provinsi DKI Jakarta, jumlah penduduk miskin berkisar 372,26 ribu jiwa atau sekitar 3,55 persen dari total penduduk DKI (BPS DKI Jakarta, 2019). Salah satu potret dari kemiskinan tersebut dapat dilihat dari kondisi pemukiman penduduk yang terdapat di berbagai rumah susun sederhana sewa atau yang biasa disebut Rusunawa, serta juga pemukiman kumuh yang terdapat di bantaran sungai. Kawasan pemukiman semacam ini seringkali menimbulkan dampak tak hanya pada aspek ekonomi, namun juga sosial (Voorts, 2018). Permasalahan sosial dan ekonomi ini yang kemudian dapat menurunkan kondisi kualitas hidup.

Problematika sosial lain juga dapat muncul apabila komunitas penduduk terpaksa dipindahkan dari satu pemukiman ke pemukiman lain yang memiliki lingkungan, tata ruang, dan pola kemasyarakatan yang berbeda. Misalnya yang terjadi pada warga Bukit Duri, Tebet. Warga Bukit Duri selama ini tinggal di daerah bantaran aliran sungai Ciliwung. Pada tahun 2016 yang lalu, warga Bukit Duri sendiri telah direlokasi dari kediaman tempat tinggal mereka, sehubungan dengan adanya program normalisasi Kali Ciliwung oleh pemerintah provinsi DKI Jakarta.

Sebagian warga dari RW 10,11, dan 12 Bukit Duri harus dipindah ke Rusunawa yang lokasinya jauh, yaitu di Rusunawa Rawa Bebek di kawasan Cakung Jakarta Timur. Kondisi Rusunawa Rawa Bebek sendiri dapat disebut bersih dan terdapat beberapa fasilitas yang dapat dipergunakan oleh warga (Gremico, 2016). Meskipun demikian, warga tetap perlu beradaptasi dari lingkungan sebelumnya yang menggunakan model rumah tinggal dan telah ditempati dalam kurun waktu yang lama, menjadi tempat tinggal yang berkonsep rumah susun dan bersistem sewa. Perubahan sosial yang terjadi pada warga Bukit Duri sebagai dampak dari perubahan tempat tinggal ini secara tidak langsung juga turut mengubah pola interaksi sosial antar warga dan sistem komunitas yang telah dibangun selama ini.

Sebelum program intervensi sosial ini dilakukan, tiga orang mahasiswa Fakultas Psikologi Universitas YARSI telah melakukan asesmen awal pada masyarakat di Rusunawa Rawa Bebek pada 22 Juli hingga 10 Agustus 2019. Asesmen terutama dilakukan pada warga Rusunawa yang berusia remaja. Jumlah warga berusia remaja di Rawa Bebek secara keseluruhan adalah kurang lebih 468 orang untuk usia 17-25 tahun dan 291 orang untuk usia 14-16 tahun. Meskipun secara kuantitas terbilang cukup besar, namun di sisi lain jumlah tersebut tidak merepresentasikan tingkat keaktifan dan produktivitas yang bersangkutan. Sebagian besar remaja ini semenjak dipindahkan dari Bukit Duri ke Rusunawa Rawa Bebek kemudian mengalami putus sekolah, di mana hanya sekitar $60 \%$ orang yang masih bersekolah dan sebagian juga masih bersekolah di Bukit Duri.

Berdasarkan hasil observasi dan wawancara yang dilakukan kepada beberapa warga khususnya empat ketua RT di lingkungan rusun, ditemukan bahwa kegiatan para remaja di lingkungan rusun Rawa Bebek ketika berkumpul lebih banyak menggunakan gadget atau handphone. Selain itu antar kelompok remaja juga kurang berinteraksi dan berbaur satu sama lain, khususnya antara remaja rusun yang berasal dari Bukit Duri dengan pemuda yang berasal dari daerah lain. Hal ini menyebabkan kurangnya kegiatan komunitas pemuda setempat. Beberapa orang pemuda yang menjadi responden wawancara menuturkan bahwa mereka merasakan kurangnya dukungan sosial, yang kemudian berdampak pada rendahnya motivasi dan kepercayaan diri mereka untuk melakukan aktivitas yang lebih positif. 
Berbagai temuan hasil asesmen sementara di atas mengindikasikan bahwa remaja di lingkungan Rusunawa Rawa Bebek memiliki permasalahan terkait dengan interaksi antar komunitas pemuda yang terdapat di rusun, yang antara lain diimplikasikan oleh rendahnya produktivitas dan motivasi diri. Kondisi ini dapat juga dikatakan menunjukkan rendahnya sense of community pada warga usia muda. Sense of community dapat diartikan sebagai suatu ikatan emosional dengan anggota komunitas, yang mendorong keinginan untuk berbagi dan saling memenuhi kebutuhan. Sementara Saranson mendefinisikan sense of community sebagai persepsi dari anggota komunitas tentang adanya tiga hal, yaitu: kesamaan dan kemiripan dengan anggota lain, ketergantungan atau dependensi pada anggota lain, serta keinginan menjaga interdependensi yang ada dengan memberikan sesuatu atau melakukan sesuatu yang dikehendaki oleh anggota lain (Wibowo, Pelupessy, \& Narhetali, 2011).

Salah satu aspek yang terdapat dalam sense of community adalah adanya hubungan emosional dengan anggota komunitas yang lain. Ketika seorang warga memiliki relasi yang bersifat emosional dengan warga yang lain, maka koneksivitas tersebut dapat meningkatkan emosi positif pada diri yang bersangkutan. Penelitian Siedlecki, Salthouse, Oishi, dan Jeswani (2013) menemukan bahwa dukungan sosial dalam berbagai bentuk dapat mempengaruhi kepuasan hidup, afeksi positif, serta subjective well-being.

Perasaan dependensi dan hubungan saling mempengaruhi antar anggota komunitas yang muncul dari adanya sense of community, dapat meningkatkan hubungan personal, komunikasi antar anggota, dan persepsi mengenai adanya dukungan sosial. Sense of community sendiri berkaitan erat dengan kohesivitas dan interaksi dalam bertetangga (Nasar \& Julian, 1995). Sejumlah hasil penelitian juga menunjukkan bahwa sense of community dapat meningkatkan sosial dan subjective well-being (Cicognani et al, 2008), serta kepuasan dan kualitas hidup (Hombrados-Mendieta, Gomez-Jacinto, Dominguez-Fuentes, \& Garcia-Leiva, 2013). Oleh karena itu, usulan program yang hendak ditawarkan oleh program ini adalah lebih berfokus pada penguatan sense of community pada warga berusia remaja di lingkungan Rusunawa Rawa Bebek.

Desain program pemberdayaan pada masyarakat ini sendiri akan berlandaskan pada metode informational dan structural strategies dari Steg \& Vlek (2009). Informational strategies berfokus pada pengubahan motivasi, persepsi, dan kognisi dari sasaran intervensi. Strategi ini dapat diimplementasikan dalam wujud pemberian informasi, persuasi, dan penguatan norma dan dukungan sosial. Sedangkan tahapan structural strategies berfokus pada pengubahan situasi dan kondisi yang dapat mendorong timbulnya perilaku yang ditargetkan. Strategi ini dapat meliputi pembentukan sistem organisasi, yang disertai adanya regulasi dan rule/aturan yang dapat memberikan reinforcement (penguatan) kepada anggota untuk melakukan perilaku yang ditargetkan. Adapun program yang diajukan dalam proposal ini hanya akan mencakup tahapan informational strategies terlebih dahulu, sementara tahap structural strategies akan dilaksanakan kemudian sebagai bagian program jangka panjang pemberdayaan masyarakat.

Program pengabdian pada masyarakat ini dilaksanakan di Rusunawa Rawa Bebek, yang terletak di Kelurahan Pulo Gebang, Kecamatan Cakung, Kota Jakarta Timur. Rusunawa Rawa Bebek terdiri dari 8 blok, dengan empat blok di antaranya dihuni oleh mayoritas warga yang direlokasi dari kawasan Bukit Duri, Jakarta Selatan. Sementara sebagian warga lainnya kebanyakan berasal dari Pasar Ikan, Jakarta Utara. 
Sasaran dari program ini adalah warga usia remaja (14 hingga 25 tahun). Sebagian besar penduduk Rawa Bebek yang berusia tersebut diketahui banyak yang putus sekolah ataupun belum memiliki pekerjaan. Di samping itu, mereka juga memiliki tingkat keaktifan sosial yang rendah, ditambah tidak adanya wadah komunitas yang dapat memfasilitasi pengembangan diri mereka ataupun sebagai bentuk kontribusi terhadap lingkungan sekitar. Oleh karena itu, untuk meningkatkan sense of community, interaksi, dan kohesivitas pada warga rusun keseluruhan, maka perlu dimulai dari komunitas usia produktif ini.

Rumah susun sederhana merupakan salah satu sektor kawasan di Jabodetabek yang pada umumnya memiliki warga dengan tingkat ekonomi dan kualitas hidup yang rendah. Salah satu faktor penyebab dari kualitas hidup yang rendah tersebut adalah terletak pada aspek interaksi dan dukungan sosial antar warga, yang sangat ditentukan oleh sense of community (Zainal, Kaur, Ahmad, \& Khalili, 2012). Terlebih lagi mengingat mayoritas warga yang ada di rusun tersebut adalah pindahan dari daerah lain, seperti yang terjadi di Rusunawa Rawa Bebek, Cakung (Gremico, 2016). Komponen masyarakat yang tergolong dalam usia produktif dan memiliki kapabilitas yang lebih tinggi untuk dapat menggerakkan komunitas adalah warga usia muda atau remaja. Namun, berdasarkan asesmen awal sebagaimana dijelaskan di atas, ditemukan bahwa para remaja di rusun Rawa Bebek sendiri memiliki tingkat kepedulian, kesadaran, dan motivasi sosial yang rendah.

Oleh karena itu, program ini ditujukan untuk menguatkan sense of community pada remaja Rawa Bebek, dengan harapan hal tersebut akan mendorong integrasi sosial antar remaja setempat, yang selanjutnya dapat berkembang menjadi suatu komunitas yang produktif dan secara tidak langsung dapat turut memobilisasi dan meningkatkan kohesivitas pada lingkungannya. Target dari program ini adalah tumbuhnya rasa berkomunitas dalam diri pemuda Rawa Bebek. Indikator keberhasilan program adalah meningkatnya jumlah anggota Karang Taruna Rawa Bebek dan berikut aktivitas yang dijalankan. Diharapkan para remaja akan memiliki motivasi, kesadaran, dan kepedulian sosial yang tinggi, yang pada akhirnya dapat menjadi modal sosial bagi masyarakat/lingkungan sekitar untuk lebih meningkatkan kualitas hidupnya pada aspek sosial.

\section{Metode Pengabdian}

\section{Bentuk dan Tahapan}

Program intervensi psikososial ini akan diaplikasikan dalam bentuk psikoedukasi, yang akan dilakukan bertahap selama satu bulan. Konsep dasarnya adalah informational strategies (Steg \& Vlek, 2009). Berdasarkan konsep dasar tersebut, maka intervensi ini akan melalui beberapa sesi, yaitu :

1. Focus Group Discussion (FGD). Pada sesi ini, peserta diajak untuk berdiskusi mengenai bagaimana kondisi sosial di Rusunawa, masalah apa saja yang muncul, dan bagaimana interaksi antar pemuda dan antar warga sejauh ini. FGD ini ditujukan untuk mencari strategi pemecahan masalah bersama, sebelum melanjutkan ke tahap intervensi selanjutnya. FGD dilakukan sebelum dan sesudah pelatihan. Tahap pertama ini dilaksanakan selama beberapa waktu dalam satu bulan. 
2. Pelatihan urgensi komunitas. Pada sesi ini, peserta akan dipaparkan materi mengenai pentingnya berorganisasi dan memiliki komunitas. Lalu peserta diajak untuk menganalisis pola pikirnya sendiri selama ini.

3. Games teamwork. Pada sesi ini, peserta akan dibagi beberapa kelompok yang diacak, lalu diajak untuk bermain sebuah games di mana mereka harus bekerjasama sebagai tim dalam memecahkan suatu masalah/kasus yang diberikan oleh trainer. Tahap kedua dan ketiga dilaksanakan dalam satu hari.

4. Evaluasi efek intervensi dilakukan dengan memberikan pre-test dan post-test. Pre-test diberikan sebelum pelatihan sedangkan post-test diberikan setelah pelatihan. Instrumen pengukuran yang dipergunakan dalam pre-test dan post-test adalah Skala Brief Senses of Community Scale (BSCS) yang diadaptasi dari penelitian Peterson, Speer, dan McMillan (2008). Setelah itu akan dianalisis perbedaan sense of community pada peserta, antara sebelum dan sesudah diberikan intervensi. Berdasarkan hasil analisis tersebut, dapat disimpulkan bagaimana pengaruh dari intervensi yang diberikan dalam meningkatkan sense of community pada remaja Rusun Rawa Bebek.

\section{Sasaran, Waktu, dan Tempat}

Sasaran dari program ini adalah warga Rusun Rawa Bebek khususnya usia remaja, khususnya Karang Taruna Rawa Bebek. Sebagian besar penduduk yang berusia remaja diketahui masih banyak yang belum memiliki pekerjaan tetap ataupun sumber penghasilan rutin yang jelas, serta memiliki tingkat kesejahteraan sosial yang dapat dikatakan cukup rendah. Dengan demikian, kelompok warga usia ini akan memerlukan wadah yang positif untuk dapat berkontribusi secara aktif dalam masyarakat.

Rangkaian proses asesmen dilaksanakan di Rusunawa Rawa Bebek, Cakung, Jakarta sepanjang bulan Januari hingga Februari 2020. Focus Group Discussion (FGD) dilakukan pada tanggal 9 Februari 2020. Pelatihan inti dilaksanakan di blok C Rusunawa Rawa Bebek, Kemayoran, pada tanggal 8 Maret 2020, pukul 09.00 hingga 13.00 WIB, dan diikuti oleh 17 orang remaja anggota Karang Taruna Rawa Bebek.

\section{Pelaksanaan}

Berdasarkan hasil asesmen, diperoleh beberapa permasalahan pada remaja Rawa Bebek. Pertama, seringnya terjadi konflik yang terkadang disebabkan oleh hal-hal yang tidak prinsipil. Penyebabnya antara lain karena warga setempat merupakan warga relokasi dari dua daerah yang berbeda di Jakarta, sehingga terkadang masih belum menyatu. Kemudian permasalahan lain adalah masih banyaknya remaja yang menghabiskan waktu untuk hal yang kurang berfaedah dan kurang mampu mengekspresikan pendapatnya dengan tepat. Oleh karena itu, pelatihan akan diisi dengan materi mengenai regulasi emosi, kontrol diri, dan perilaku asertif, serta manajemen waktu dan komitmen berorganisasi. Sehingga, selain dapat memiliki sense of community, sebagai anggota komunitas peserta sekaligus diharapkan dapat memperbaiki karakter emosinya.

Rangkaian kegiatan pelatihan dibuka dengan ice breaking yang diberikan oleh mahasiswa. Setelah itu diberikan pre-test berupa peserta diminta untuk mengisi skala BSCS. Setelah itu 
dilanjutkan pemberian materi yang pertama, yaitu mengenai urgensi berkomunitas (Gambar 1). Setelah itu, materi yang kedua yaitu regulasi emosi dan dilanjutkan materi ketiga mengenai kontrol diri.

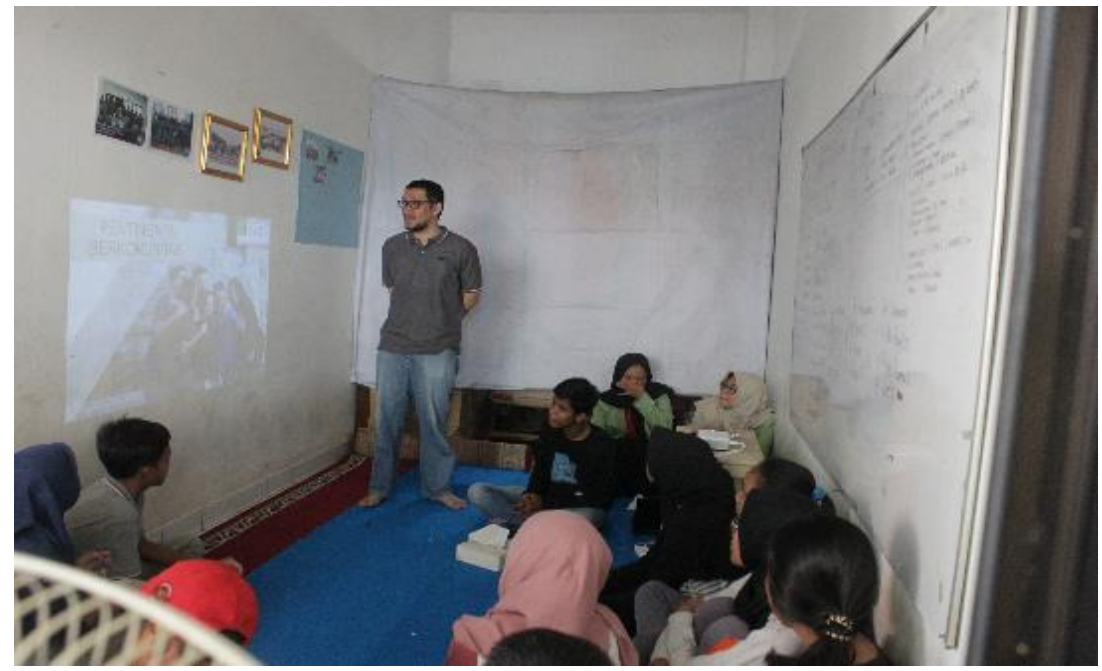

Gambar 1. Penyampaian materi urgensi komunitas

Kemudian masuk ke materi games teamwork berupa permainan maju mundur. Dalam games ini, peserta diminta untuk secara bersama-sama melakukan gerakan, namun harus berkebalikan dari yang diinstruksikan oleh trainer. Setelah games, peserta diberikan materi mengenai manajemen waktu dan perilaku asertif. Setelah itu, diberikan games teamwork yang kedua, yaitu tebak tokoh (Gambar 2). Dalam games ini, peserta secara berkelompok diminta bekerjasama untuk menebak seorang tokoh yang ada di kartu yang diperlihatkan trainer.

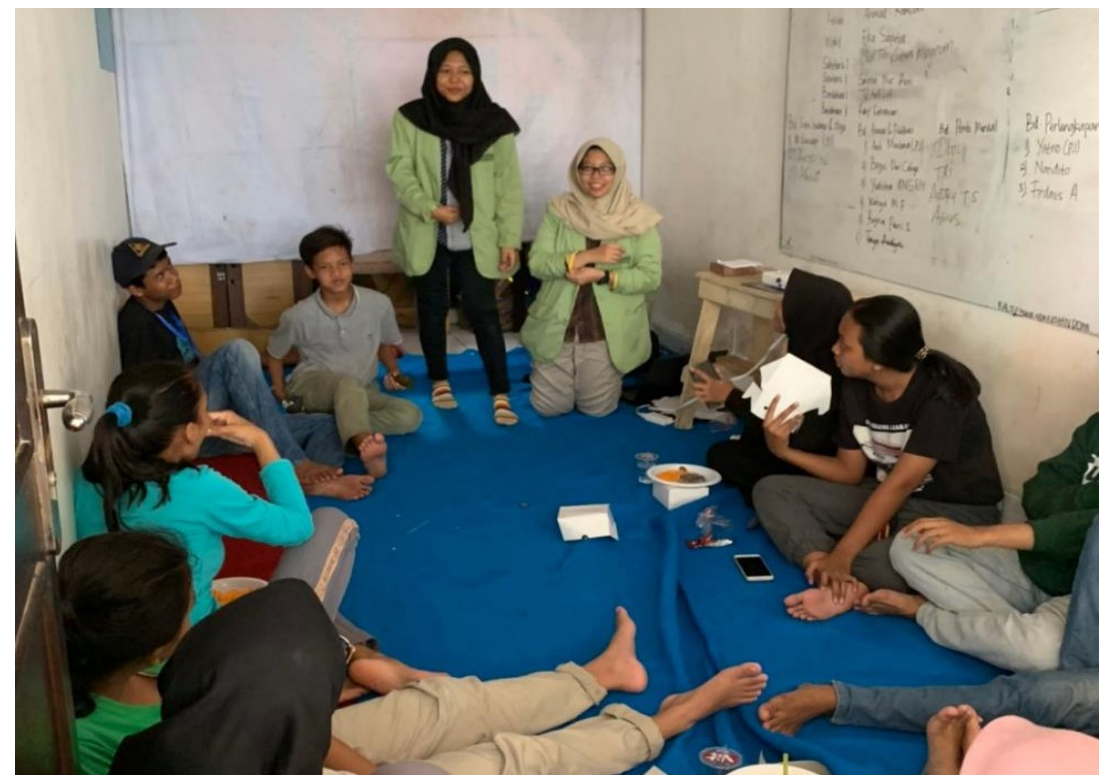

Gambar 2. Games teamwork

Pelatihan ditutup dengan materi mengenai komitmen berorganisasi. Sebelum penutupan, peserta terlebih dahulu mengisi post-test berupa skala BSCS lagi, ditambah form evaluasi pelatihan dan pengetahuan mengenai materi yang diberikan (Gambar 3). 


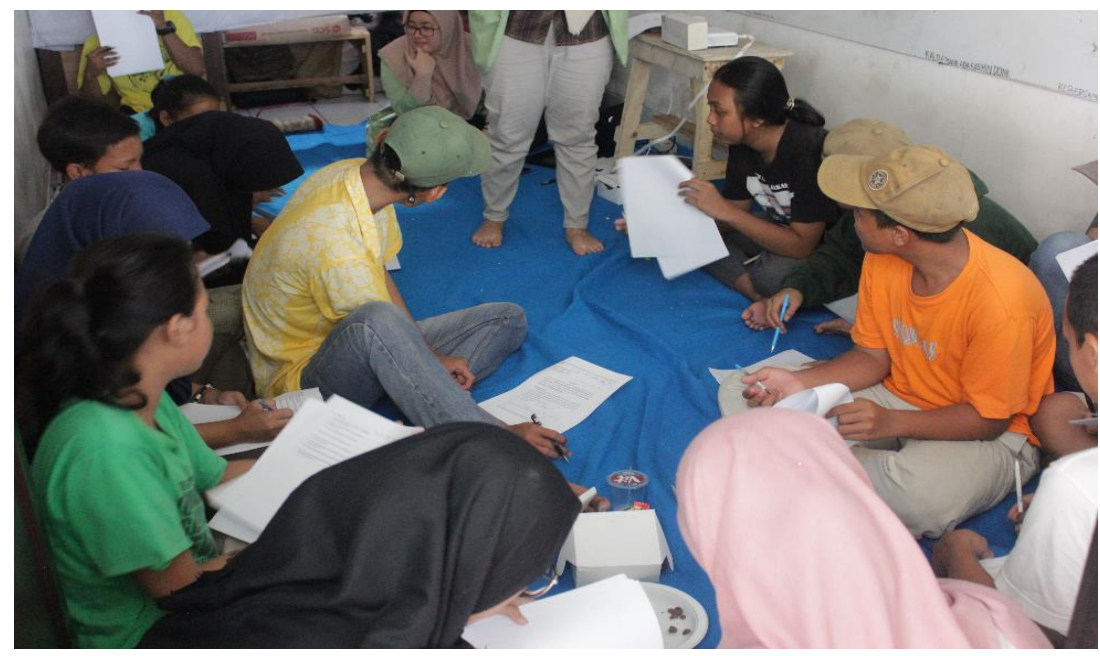

Gambar 3. Pengisian post-test

\section{Hasil dan Diskusi}

Berdasarkan hasil FGD dan juga wawancara dengan beberapa orang anggota Karang Taruna Rawa Bebek, diperoleh beberapa permasalahan di Rusunawa Rawa Bebek. Permasalahan intrapersonal yang ada antara lain menyangkut regulasi emosi, kontrol diri, dan perilaku asertif. Dalam hal ini, hasil penelitian Zhao, Kong, dan Wang (2013) menunjukkan bahwa dukungan sosial dan kecerdasan emosi merupakan faktor yang menentukan bagaimana rasa malu yang dimiliki seseorang dapat berpengaruh pada well-being-nya. Dukungan sosial yang rendah yang dialami oleh warga rusun penyintas relokasi, ditambah rendahnya kecerdasan emosi mereka, secara tidak langsung memperkuat rasa malu dan kurangnya asertifitas mereka dalam lingkungan sosial, sekaligus` menyebabkan mereka kurang merasa sejahtera secara psikologis.

Sedangkan permasalahan interpersonal yang ditemukan dari proses asesmen adalah manajemen waktu dan komitmen berorganisasi. Hasil studi yang dilakukan oleh Kuusio, Heponiemi, Sinervo, dan Elovainio (2010) menyebutkan faktor-faktor psikososial sebagai pendukung dari timbulnya komitmen berorganisasi. Faktor-faktor psikososial seperti di antaranya keberadaan teman sebaya yang memiliki ikatan emosional.

Efek dari pelatihan terhadap peningkatan sense of community diukur dengan melihat perubahan skor rata-rata peserta antara pre-test dengan post-test pelatihan yang menggunakan angket BSCS. Hasilnya ditemukan bahwa mean atau rata-rata skor sense of community yang diperoleh peserta meningkat tipis dari 30,69 menjadi 31,77. Hasil ini menunjukkan bahwa perasaan memiliki dan keterikatan peserta terhadap komunitasnya meningkat setelah diberikan pelatihan. Hasil pre dan post-test dapat dilihat pada Gambar 4. 


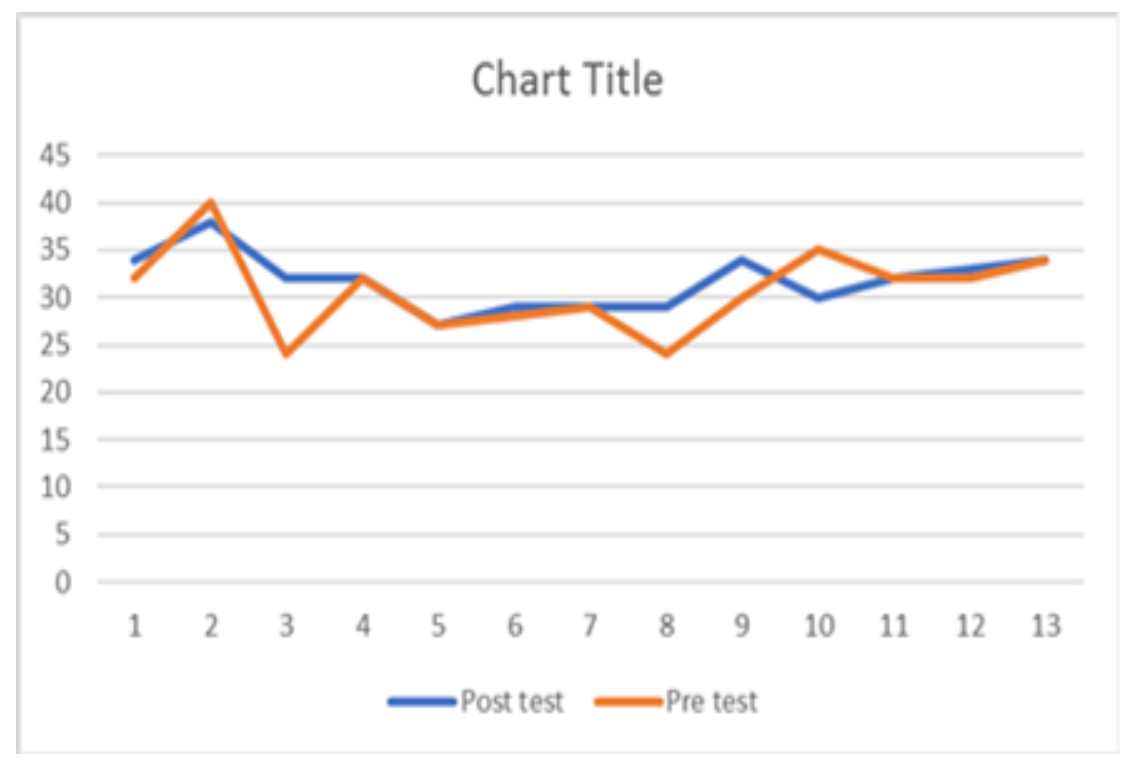

Gambar 4. Perbandingan skor pre-test dan post-test pelatihan

Pelatihan ini menekankan pada pemaparan materi mengenai urgensi komunitas dan juga materi-materi lain yang berdasarkan kepada beberapa permasalahan yang ditemukan dari asesmen. Sejumlah penelitian memperlihatkan bahwa pemaparan informasi ditemukan dapat meningkatkan kesadaran akan substansi yang dikandung oleh informasi tersebut. Di samping itu, pelatihan ini juga menggunakan dua kali games teamwork, dengan maksud dapat memfasilitasi peserta untuk saling berinteraksi dan bekerjasama, sehingga selanjutnya dapat meningkatkan rasa keteriaktan dan kohesivitas mereka. Terdapat beberapa pelatihan terdahulu yang menggunakan metode teamwork ataupun team building, yang terbukti mampu meningkatkan kohesivitas pada kelompok, seperti misalnya pelatihan yang dilakukan oleh Setianingtyas dan Darokah (2015) serta Bachroni (2011).

Sementara itu, hasil evaluasi kegiatan yang diberikan oleh peserta menunjukkan, rata-rata peserta cenderung puas dengan pelaksanaan kegiatan. Sebanyak 70,59\% peserta puas dengan manfaat pelatihan yang diberikan. Terkait kejelasan materi dan waktu pelaksanaan, mayoritas peserta juga menyatakan puas. Sementara terdapat 8 orang atau $47 \%$ peserta yang merasa fasilitas pelatihan kurang atau tidak memadai. Hasil evaluasi kegiatan selengkapnya dapat dilihat pada Tabel 1.

Tabel 1. Rekapitulasi Evaluasi Kegiatan

\begin{tabular}{|l|c|c|c|c|}
\hline \multicolumn{1}{|c|}{ Aspek yang dinilai } & $\begin{array}{c}\text { Tidak } \\
\text { Memuaskan } \\
\mathbf{( \%}\end{array}$ & $\begin{array}{c}\text { Kurang } \\
\text { Memuaskan } \\
\mathbf{( \%} \\
\text { responden) }\end{array}$ & $\begin{array}{c}\text { Memuaskan } \\
\mathbf{( \%} \\
\text { responden) }\end{array}$ & $\begin{array}{c}\text { Sangat } \\
\text { Memuaskan } \\
\mathbf{( \% )} \\
\text { responden) }\end{array}$ \\
\hline Kejelasan materi yang disampaikan & 0 & $2(11,76 \%)$ & $13(76,4 \%)$ & $2(11,76 \%)$ \\
\hline Waktu pelaksanaan & 0 & $3(17,65 \%)$ & $11(64,7 \%)$ & $3(17,65 \%)$ \\
\hline Fasilitas kegiatan & $1(5,8 \%)$ & $7(41,18 \%)$ & $8(47,05 \%)$ & $1(5,8 \%)$ \\
\hline Manfaat pelatihan & 0 & $2(11,76 \%)$ & $12(70,59 \%)$ & $3(17,65 \%)$ \\
\hline
\end{tabular}

Sejauh ini program yang dijalankan di Rusun Rawa Bebek ini berjalan sesuai dengan harapan dan tidak mengalami hambatan berarti. Namun, terkait dengan efektifitas atau dampak dari intervensi yang dilakukan, perlu ditinjau lebih jauh, mengingat perubahan pengetahuan dan 
perilaku sebagai hasil dari pelatihan tidak terlalu signifikan. Maka dari itu, perlu ditindaklanjuti dengan model intervensi lain seperti psikoedukasi atau penerapan sistem. Selain itu, permasalahan yang ditemukan dari hasil FGD seperti permasalahan regulasi dan kontrol diri serta manajemen waktu, dapat diberikan intervensi secara parsial namun tetap integral dalam program yang sejalan.

Selain itu, hasil diskusi dengan Karang Taruna Rawa Bebek pasca pelatihan juga menunjukkan bahwa kegiatan program yang telah dilaksanakan ini perlu untuk ditindaklanjuti, terutama dengan bekerjasama dengan instansi atau dinas terkait. Diharapkan dengan adanya sinergitas tersebut, maka program yang dijalankan dapat mencakup waktu yang lebih lama dan intrumen pengukuran yang lebih rapi, sehingga dapat memiliki dampak jangka panjang yang lebih koheren.

\section{Kesimpulan}

Hasil intervensi komunitas yang dilakukan melalui pelatihan terbukti mampu meningkatkan pengetahuan dan kesadaran komunitas pemuda Rawa Bebek terkait rasa memiliki komunitasnya sebesar $1,08 \%$. Namun, efektifivitas dari pengaruh intervensi ini masih perlu dikaji lebih lanjut dan diteruskan dalam wujud program lanjutan jangka panjang, mengingat masih terdapatnya kekurangan dalam metode evaluasi.

Selanjutnya akan dilakukan kegiatan penelitian dan pengabdian kepada masyarakat lanjutan. Ketika tulisan ini diangkat, penulis dan tim tengah mengadakan penelitian mengenai sense of community dan resiliensi komunitas pada warga Rawa Bebek. Berikutnya berdasarkan hasil penelitian tersebut akan dilakukan kembali intervensi psikososial, khususnya yang menyangkut bagaimana mengoptimalkan sense of community pada warga dalam menghadapi pandemi Covid19.

\section{Saran}

Untuk pihak pengelola Rusunawa, disarankan agar membuat sistem yang dapat memperkuat keterikatan antar anggota komunitas masyarakat, seperti misalnya mengadakan berbagai kegiatan atau aktivitas yang melibatkan kerjasama antar kelompok warga dari asal daerah relokasi yang berbeda. Sedangkan kepada komunitas Karang Taruna Rawa Bebek, agar dapat lebih bersinergi dengan pemuda dari berbagai blok yang ada di Rusunawa untuk menyebarkan dan menciptakan suasana kebersamaan dan rasa sebagai satu kesatuan. Dapat juga mengaktifkan para anggota untuk turut serta dalam program-program ataupun kegiatan-kegiatan dari Perguruan Tinggi/LSM lain yang serupa.

\section{Pernyataan}

Melalui tulisan ini, penulis hendak mengucapkan terima kasih yang sebesar-besarnya kepada pihak Yayasan YARSI yang telah menyokong pendanaan bagi pelaksanaan kegiatan pengabdian kepada masyarakat ini melalui skema hibah internal Universitas YARSI. Terima kasih juga kami haturkan kepada pihak pengelola Rusunawa Rawa Bebek, para ketua RT, warga, serta tentunya ketua dan para anggota Karang Taruna Rawa Bebek yang telah membantu dan berpartisipasi penuh dalam kegiatan yang kami selenggarakan di komunitas setempat. 


\section{Referensi}

Bachroni, M. (2011). Pelatihan Pembentukan Tim untuk Meningkatkan Kohesivitas Tim pada Kopertis V Yogyakarta. Jurnal Psikologi, 38(1), 40-51. https://doi.org/10.22146/jpsi.7663

BPS DKI Jakarta. (2019). Kemiskinan dan Ketimpangan. diunduh dari https://www.bps.go.id/subject/23/kemiskinan-dan-ketimpangan.html pada 12 November 2019.

Cicognani, E. et al. (2008). Sosial Participation, Sense of community and Sosial Well Being: A Study on American, Italian and Iranian University Students. Sosial Indicator Research, 89, 97-112. http://dx.doi.org/10.1007/s11205-007-9222-3

Gremico, A. (2016). Memulai hidup di hunian baru. diunduh dari https://tirto.id/memulai-hidupdi-hunian-baru-bRWo pada 10 Desember 2019.

Hombrados-Mendieta, M.I., Gomez-Jacinto, L., Dominguez-Fuentes, J.M. and Garcia-Leiva, P. (2013). Sense of community and Satisfaction With Life Among Immigrants and The Native Population. Journal of Community Psychology, 41(5), 601-614. https://doi.org/10.1002/jcop.21559

Kuusio, H., Heponiemi, T., Sinervo, T., \& Elovainio, M. (2010). Organizational commitment among general practitioners: A cross-sectional study of the role of psychosocial factors. Scandinavian Journal of Primary Health Care, 28(2), 108-114. https://doi.org/10.3109/02813431003779647

Nasar, J.L \& Julian, D. A. (1995) The Psychological Sense of Community in the Neighborhood, Journal of the American Planning Association, 61:2, 178-184, DOI: $10.1080 / 01944369508975631$

Peterson, N.A., Speer, P.W. \& McMillan, D.W. (2008), Validation of A brief sense of community scale: Confirmation of the principal theory of sense of community. Journal of Community Psychology, 36(1), 61-73. https://doi.org/10.1002/jcop.20217

Setianingtyas, A.F. \& Darokah, M. (2015). Pengaruh Pelatihan Team Building untuk Meningkatkan Kohesivitas Tim Kerja di Inna Garuda Yogyakarta. Empathy, vol. 3, no. 1. https://www.neliti.com/publications/242040.

Siedlecki, K. L., Salthouse, T. A., Oishi, S., \& Jeswani, S. (2014). The Relationship Between Social Support and Subjective Well-Being Across Age. Social indicators research, 117(2), 561-576. https://doi.org/10.1007/s11205-013-0361-4

Steg, L. \& Vlek, C. (2009). Encouraging Pro-Environmental Behavior: An Integrative Review and Research Agenda. Journal of Environmental Psychology, 29 ,309-317. https://doi.org/10.1016/j.jenvp.2008.10.004

Voorst, R.V. (2018). Tempat Terbaik di Dunia. Tangerang: Marjin Kiri.

Wibowo, I., Pelupessy, D. C., \& Narhetali, E. (2011). Psikologi Komunitas. Depok: LPSP3UI

Zainal, N. R., Kaur, G., Ahmad, N. A., \& Khalili, J. M. (2012). Housing conditions and quality of life of the urban poor in Malaysia. Procedia-Social and Behavioral Sciences, 50, 827-838. https://doi.org/10.1016/j.sbspro.2012.08.085

Zhao, J., Kong, F., \& Wang, Y. (2013). Shyness and Subjective well-being: the Role of Emotional Intelligence and Sosial Support. Sosial Indicators Research, 114, 891-900. https://doi.org/10.1007/s11205-012-0178-6 